1. Wilmut, !., Schnieke, A.E., McWhit, 1., Kind, A.J. \& Campbell, K.H.S. Nature 385 810-813 (1997).

2. Gurdon, J.B., Laskey, R.A. \& Reeves, O.R. J. Embryol. Exp. Morph. 34, 93-112(1973).

3. Campbell, K.H.S., MCWhir, J., Ritchie, W.A \& Wilmut, i. Nature 380, 64-66 (1996). 4. Berreby, D. Slate [online] March 1 (1997)
Public opinion on human cloning is highly sceptical, although, in one poll, 7 per cent of Americans said they would clone themselves if given the chance. Many scientists, including the Roslin researchers, have used terms such as "offensive" and "repugnant" in reference to human cloning. However, while the ethical and technical barriers to cloning may prove insurmountable, two issues are worth keeping in mind. First, there could be rare circumstances in the future where cloning technology would have medical benefits. Harold Varmus, the director of the National Institutes of Health, recently told a congressional committee that infertility might be one such example. Second, a clone would indisputably not be identical to the person it was derived from. One scientist amused a congressional hearing by noting that although a hypothetical clone of the actor Mel Gibson would look just like him, it is Gibson's "charm and personality" that make him who he is. A transplanted nucleus would develop in a different cytoplasmic milieu, the fetus in a different womb, the embryo (and child) in a unique environment. "This triumph of genetic engineering," writes David Berreby of Dolly, "might well mark the defeat of the idea that genes determine who and what we are."4 Applying the recently reported cloning successes will help create improved transgenic animals for biotechnology and reduce the numbers of animals necessary for medical studies. Noting the technical as well as ethical complexities, Wilmut (an agnostic) says that "to contemplate using our present technique on humans would be quite inhuman". He is absolutely right, but it is important that society not prematurely deny itself the potentially profound insights into mammalian development and medical benefits that Dolly heralds.

\section{Five years after}

The inaugural issue of Nature Genetics five years ago contained an introduction written by the then editor of Nature, John Maddox, outlining how Nature's new creation would find its own independent niche in the rapidly shifting landscape of modern biology. In celebrating the quintennial anniversary of Nature Genetics, it is interesting to look back at how the journal has fared in meeting the goals laid out before it. The primary aim of Nature Genetics was to provide a conspicuous vehicle for advances "about the link between genome structure and disease". Nature Genetics has presented numerous exciting advances fitting this broad description, and such studies continue to be welcomed. Other areas highlighted in that opening editorial, including gene therapy, forensic science and even the occasional algorithm, have appeared frequently. Overall, the journal's efforts to uphold "the same criteria of excellence" as Nature itself are underscored by a gratifying 'impact factor' and a rising circulation that should surpass 6,000 this year.

But, to remain successful, any respectable journal must evolve and heed the shifting goals and interests of its readers and the community it represents. (For example, when Cell debuted in 1974, it was with a quaint emphasis on the 'biology of cells and their viruses.) Our pledge in 1992 was to provide "a vehicle for the publication of all research [in all organisms] that promises to illuminate human genetics". Perhaps Nature Genetics is guilty of not stressing this enough, but the importance of such a balanced approach is nicely exemplified by Bassett and colleagues on page 339 of this issue. This report also marks the birth of a long-overdue feature in Nature Genetics called 'New Technology', to help communicate "technical innovations with a bearing on the understanding of the human genome." Another area destined for greater exposure in these pages is functional genomics, as discussed by Fields on page 325, embracing "the elucidation of the mechanisms by which genes determine the behaviour of the cells that carry them". Given all this and the human genome project heading towards completion over the next five years or so, there is plenty of "grist for the mill of Nature Genetics". 